\title{
Impact Of Training On The Performance Of School Teachers
}

\author{
NOVA SYAFRINA \\ Riau College of Economics \\ Jl. HR. Subrantas 57 Panam Pekanbaru 28293 Tel. (0761) 63237 \\ Email : nova.syafrina80@gmail.com
}

\begin{abstract}
The purpose of this study was to determine the effect of training on teacher performance at SMK Negeri Pertanian Terpadu, Riau Province. This research was conducted at Integrated Agriculture State Vocational School, Riau Province. This research was SMK Negeri Integrated Agriculture, Riau Province. sample in this study took the entire population, namely 89 people. The results based on hypothesis testing can be stated that training has a significant effect on performance. It is known that the contribution of training to performance is $37.7 \%$, the rest is explained by variations in variables that do not exist in this study.
\end{abstract}

Keywords: Training, Teacher Performance

\section{PRELIMINARY}

According to Law No. 20 of 2003 article 1 paragraph 1 concerning National Education, education is a conscious and planned effort to create a learning atmosphere and learning process so that students actively develop their potential to have religious spiritual strength, self-knowledge, personality, intelligence., noble character and skills needed by himself, society, nation and state(Iskamto 2019; Yulihardi and Iskamto 2018). All things related to education, starting from the educational curriculum, education costs, educational facilities and infrastructure, as well as several other things become meaningless if the interaction of teachers and students does not go well. However, good interactions between teachers and students are the essence of education(Iskamto 2020; Iskamto, Srimulatsih, and Ansori 2021).

Given the importance of teacher performance, principals must foster good relations with teachers by paying attention to what the needs of teachers want, including providing education and training. In addition, schools must also pay attention to how to build and motivate teachers to be able to work more effectively and responsibly so that school goals are achieved previously. With the awareness of the importance of education and training for teachers, it is hoped that teachers can provide maximum performance for their students(Iskamto et al. 2020).

The development of the world of education in Indonesia has made significant progress. The establishment of industry-oriented educational establishments is also growing. This development can be seen from the establishment of educational institutions such as the Integrated Agriculture State Vocational School of Riau Province. The Integrated Agriculture State Vocational School of Riau Province is supported by competent teaching staff in their fields as well as adequate infrastructure facilities and strategic locations within reach of students and for students outside the city, dormitories are provided.

The problem of teachers is very important, because the quality of teachers also determines the quality of education. While the quality of education will determine the quality of the younger generation, as prospective 


\section{https://adpebi.com/index.php/hbr}

citizens and society. The problem of teacher quality is very dependent on the teacher education system as a sub-national education system which is a key factor and has a very strategic role. The degree of quality of teacher education is determined by the level of quality of all components, each of which contributes to the overall teacher education system.

One of the factors that are considered important for improving the quality of teachers is the existence of training for teachers. Training activities for teachers are basically an integral part of management in the field of manpower in schools and are an effort to develop teacher knowledge and skills so that in turn it is hoped that teachers can gain a competitive advantage and can provide the best service.

In carrying out his duties as a teacher at the Integrated Agriculture State Vocational School of Prov. Riau, then a program to improve the ability and skills of teachers is made, namely by providing training, this is intended to increase the knowledge and expertise of the teachers of the Integrated Agriculture State Vocational School of Prov. Riau. Here are some types of teacher training at the State Integrated Agriculture Vocational School of Prov. Riau.

With this training, quality human resources will be produced and able to give the best contribution in achieving goals. Through this training, schools can also have teachers who are able to carry out their duties well. The exercises given to teachers also often encourage teachers to work hard. This is because teachers already know well the duties and responsibilities to try to improve optimal performance of their duties. Based on the background that has been described earlier, the formulation of the problem in this study is "How is the effect of training on teacher performance at the Integrated Agricultural Vocational School of Prov. Riau".

\section{LITERATURE REVIEW}

According to Widodo (2015: 82), training is a series of individual activities in systematically increasing skills and knowledge so that they are able to have professional performance in their fields. According to Simamora (2012: 287) training is a series of development program activities that are carried out and designed to improve knowledge skills, experience, or change the attitude of a person or individual. According to Rivai (2012: 54) training is a process of systematically changing employee behavior to achieve organizational goals.

\section{Training indicators}

Garry Desller (2014:244) states that the indicators in training are as follows (a) Instructor, the instructor is a capable teacher who provides enormous assistance to the success of the training program. The instructor explains the overall purpose of the job to the trainee then explains the tasks specifically to see the relevance of each job and follow the correct work procedures, and have a patient nature. With Indicators: Adequate qualifications/competencies, Motivating participants, Need for feedback. (b) Participant, A trainee should be trained for the kind of work he likes and is suitable for the job, both managerial and operational participants. With Indicators: Passion for training and Desire to understand

a. Materials, Training program materials must be able to meet the needs of the organization and training participants. Training materials must be in accordance with the needs of participants or their motivation is low. With Indicators: Accuracy of material with objectives and Adding capabilities. (c) Method

The method chosen should be adapted to the type to be implemented and can be developed. Both the on the job and off the job methods. By Indicator: The training method is in accordance with the type of training and The suitability of the method with the effective one with the material

\section{Definition of performance}




\section{https://adpebi.com/index.php/hbr}

Teacher performance according to Supardi (2014: 54) is the ability of a teacher to carry out learning tasks in madrasas and be responsible for students under his guidance by increasing student learning achievements. Therefore, teacher performance can be interpreted as a condition that shows the ability a teacher in carrying out his duties at the madrasa and describes the existence of an act that is displayed by the teacher in or during learning activities.

\section{Teacher Performance Indicator}

According to Atep Yogaswara (2010:63), teacher performance indicators include:

a. Ability to plan and prepare for teaching

b. Mastery of teaching methods and strategies

c. Giving assignments to students

d. Ability to manage class

e. Ability to conduct assessment and evaluation.

\section{The Effect of Training on Teacher Performance}

According to Tiffin and Mc. Cormick in Soekarno (2009: 86). Training is part of the individual variables that influence teacher performance apart from other variables in individual variables, such as attitudes, characteristics, physical traits, interests and motivations, experience, age, gender, education, and other individual factors. Meanwhile, according to Sutomeister in Soekarno (2009: 88), expressed his opinion, that teacher performance is influenced by training which is part of the ability factor where the training in question is formal and non-formal training related to teaching and the school environment.

\section{METHOD}

This research was conducted at the State Vocational High School of Integrated Agriculture Prov. Riau, having its address at JL. Kharuddin Nasution No. Km 10, Maharatu, Marpoyan Damai, Pekanbaru City, Riau. The sample used in this study was the entire population of 89 people.

\section{Data Analysis Method}

a. Descriptive Analysis

Descriptive analysis is an analysis that describes a data that will be made either alone or in groups. The purpose of descriptive analysis is to systematically describe factual and accurate data regarding the factors and relationships between phenomena being investigated or researched (Ridwan and Akdon, 2010), in the book Correlational Quantitative Methods (Siswanto and Suyanto: 2018: 226)

\section{RESULTS AND DISCUSSION}

The use of simple linear regression data techniques in this study is intended to find a relationship between the independent variables, namely education and training on the dependent variable of teacher performance at the Integrated Agricultural State Vocational School of Riau Province, the regression results are obtained as follows:

Table 1: Regression 
https://adpebi.com/index.php/hbr

\begin{tabular}{|c|c|c|c|c|c|}
\hline \multirow[b]{2}{*}{ Model } & \multicolumn{2}{|c|}{$\begin{array}{l}\text { Unstandardized } \\
\text { Coefficients }\end{array}$} & \multirow{2}{*}{$\begin{array}{c}\text { Standardized } \\
\text { Coefficients }\end{array}$} & \multirow[b]{2}{*}{$\mathrm{T}$} & \multirow[b]{2}{*}{ Sig. } \\
\hline & B & Std. Error & & & \\
\hline $1 \quad$ (Constant) & 33,458 & 4.614 & & 7.251 & .000 \\
\hline sumx & .540 & .075 & .614 & 7.251 & .000 \\
\hline
\end{tabular}

a. Dependent Variable: sumy

Table 1 After tabulating the results of the calculation of each variable, the data are entered or processed into the SPSS version 23 computer program to see the effect of the training provided on the performance of teachers at the Integrated Agriculture State Vocational School of Riau Province. The constant value is 33,548, meaning that if there is no change in the training variable $(X=0)$, the teacher's performance at the Integrated Agriculture State Vocational School in Riau Province is 33,548 units. The regression coefficient value of the training variable is 0.540 , meaning that if the training variable increases by $1 \%$, the teacher's performance at the Integrated Agricultural Vocational School of Riau Province increases by 0.540. This shows that the training variable contributes positively to teacher performance and contributes negatively when vice versa.

\section{t test}

To prove the hypothesis, the t-test was used to determine the effect of the independent variable in explaining the dependent variable. The t-test can be known based on the data in the following table:

Table 2: T Uji Test

\begin{tabular}{|c|c|c|c|c|c|}
\hline \multirow[b]{2}{*}{ Model } & \multicolumn{2}{|c|}{$\begin{array}{l}\text { Unstandardized } \\
\text { Coefficients }\end{array}$} & \multirow{2}{*}{$\begin{array}{c}\text { Standardized } \\
\text { Coefficients }\end{array}$} & \multirow[b]{2}{*}{$\mathrm{T}$} & \multirow[b]{2}{*}{ Sig. } \\
\hline & B & Std. Error & & & \\
\hline 1 (Constant) & 33,458 & 4.614 & & 7.251 & .000 \\
\hline sumx & .540 & .075 & 614 & 7.251 & .000 \\
\hline
\end{tabular}

a. Dependent Variable: sumy

Table 2 is used to examine the effect of independent variables on the dependent variable individually. if the value of $t$ count $<\mathrm{t}$ table then $\mathrm{H} 0$ is accepted, this means that there is no significant or significant effect of the training variable on teacher performance. Conversely, if the value of $t$ arithmetic $>t$ table then $\mathrm{H} 0$ is rejected, this means that there is a significant or significant effect of the training variable on teacher performance. Value of $\mathrm{t}$ table $=\mathrm{t}$ count $=7.251>\mathrm{t}$ table $=2.370$. it means that there is a significant influence of the training variable on the teacher's performance at the Integrated Agriculture State Vocational School of Riau Province.

\section{Coefficient of Determination (R2)}




\section{https://adpebi.com/index.php/hbr}

To find out that training has an effect on teacher performance at the Integrated Agriculture State Vocational School in Riau Province, it can be seen from the correlation value of the two variables.

Table 3. Coefficient of Determination

\begin{tabular}{|l|r|r|r|r|}
\hline Model & R & R Square & Adjusted R Square & Std. Error of the Estimate \\
\hline 1 & $.614 \mathrm{a}$ & .377 & .370 & 4.472 \\
\hline
\end{tabular}

a. Predictors: (Constant), sumx

Based on table 3, it is known that the coefficient of determination (R2) is 0.377 , which shows that training on the performance of teachers at the Integrated Agriculture State Vocational School in Riau Province has an effect of $37.7 \%$. While the remaining $62.3 \%$ is influenced by other variables not examined in this study.

The coefficient of determination is used to find out how much variation of the independent variable overall to the variation of the dependent variable. Measurement is done by calculating the coefficient of determination (R2) close to 1 (one), the more precise the linear line used as an approach to research. The regression equation is always accompanied by with the coefficient of determination (R2) as a measure of fit. From the calculation results, the coefficient of determination (R2) is 0.377 or $37.7 \%$.

Based on the results of the study, the coefficient of determination of the percentage of variation in the influence given by education and training on the variation of teacher performance variables at the Integrated Agriculture State Vocational School in Riau Province was $37.7 \%$. While the remaining $62.3 \%$ is influenced by other variables not examined in this study.

\section{CONCLUSION}

It was found that the training variable contributed positively to teacher performance, so that the higher the level of training, the higher the teacher's performance at the Integrated Agriculture State Vocational School of Riau Province.From the results of the t-test test, the results of the t-count are 7.251 when compared to the $t$ table of 2.370, so that the t-count is greater than t-table, which means that training has a significant effect on the performance of teachers at the Integrated Agriculture State Vocational School of Riau Province. Based on the hypothesis test, it can be stated as follows. The test results show that training has a significant effect on performance. It is known that the contribution of training to performance is $37.7 \%$, the rest is explained by variations in variables that do not exist in this study.

\section{REFERENCES}

AA Anwar Prabu Mangkunegara. 2012. Evaluation of Human Resources Performance. Bandung : PT. Aditama Refika.

Arikunto, Suharsimi 2010. Definition of Research Variables.Rineka Cipta.Jakarta

Dessler Gary. 2009. HR Management : book 1. Jakarta : Index

Hasibuan, Malay SP 2012. Human Resource Management Sixteenth Edition, Jakarta : PT. Earth Literature 


\author{
https://adpebi.com/index.php/hbr
}

Hasibuan, Malay SP 2016. Human Resource Management. Revised Edition. Jakarta: Publisher PT Bumi Aksara

Hasibuan, Nurhalimah. 2018. The Effect of Training on Teacher Performance at SMK Negeri 1 Rarunan in Padang Lawas Regency, Sibahuan, North Sumatra Province. STIE Riau Pekanbaru

Herman Sofiandi. 2013. Human Resource Management, Yogyakarta: Graha Ilmu

Iskamto, Dedi. 2019. "Work Discipline and Its Effect on Employee Performance at PT. Prima Rintis Sejahtera Pekanbaru Unicharm Division.” Business Economics 24(1):12. doi:10.17977/um042v24i1p12-20.

Iskamto, Dedi. 2020. "The Role of Leadership and Influence on Employee Performance in the Digital Era." Journal of Business Management 17(4):470-84.

Iskamto, Dedi, Kurniati Karim, Sukono, and Talib Bon. 2020. "Impact of Employee Satisfaction on Work Discipline in Government Office in Indonesia." P. 13 in The International Conference on Industrial Engineering and Operations Management. Detroit, MI, USA,: IEOM Society International.

Iskamto, Dedi, Mahbubah Srimulatsih, and Putra Budi Ansori. 2021. "Analysis of Relationship between Leadership and Employee Performance at Manufacturing Company in Indonesia." P. 8 in Proceedings of the 11th Annual International Conference on Industrial Engineering and Operations Management. Singapore: IEOM Society International.

Yulihardi, and Dedi Iskamto. 2018. "The Influence of Work Planning, Work Motivation and Work Coordination on Employee Performance in North Sipora District, Kepulauan Regency." Eko Dan Bisnis (Riau Economics and Business Reviewe) 9(2).

Nurlaila, 2016. The Influence of Education and Training on Teacher Performance at State Vocational High School 3, Pekanbaru : STIER Riau

Octavia, Lisa. 2018. The Effect of Education and Training (DIKLAT) on Teacher Performance at SMK Negeri 1 Sintuk Toboh Gadang Padang Pariaman. Proposal: STIE Riau Pekanbaru

Rivai, Veithzal. 2009. Human Resource Management For Companies FROM Theory to Practice. Jakarta : Raja Grafindo Persada

Siagian, Sondang P. 2008. Human Resource Management. PT. Earth Literacy, Jakarta 1

Visce Weni (2016) The Effect of Training on Teacher Performance at SMP Negeri 1 cerenti Kuantan district singing. STIER. Pekanbaru

Yuniarsih, Tjutju. and Swatno. 2011. Human Resource Management. Bandung ;Alphabet 